\title{
Ephemeral Museums in Pandemic Era: Bari and the Museo Provinciale that Was There, that Has Been and Has Never \\ Been
}

\section{Andrea Leonardi}

Giuseppe De Sandi

Claudia Colella

Università degli Studi di Bari 'Aldo Moro' Dipartimento di Lettere, Lingue, Arti. Italianistica e Culture Comparate Piazza Umberto I, Bari, Italy

\section{Abstract}

The proposal introduces the theme of the communicative resilience of exhibitions during the Pandemic Era. On March 7, 2020, Italy and its museums, as well as the countless exhibitions housed in their rooms, were closed leaving hundreds, perhaps thousands, of works without the public: from the paintings of Raphael (Rome, Scuderie del Quirinale), to the tables of the Griffoni Polyptych assembled after three hundred years (Bologna, Palazzo Fava), to the statues of Canova (Rome, Palazzo Braschi), to the Sant'Antonio by Antonio Vivarini and to the San Felice in the chair by Lorenzo Lotto chased by Bernard Berenson in his Apulian 'pilgrimages' (Bari, Palazzo Ateneo). Indeed, the latter is the exhibition to which particular attention is paid here. The spaces of the ancient Museum have come back to life with the exhibition "Il Museo che non c'è. Arte, collezionismo, gusto antiquario nel Palazzo degli Studi di Bari 1875-1928". The exhibition involved lenders institutions such as Villa I Tatti - The Harvard University Center for Italian Renaissance Studies, the Central State Archive in Rome, the Pinacoteca of Bari 'Corrado Giaquinto' and several others. The exhibition in Bari was inaugurated on February 28th. After the first five days only the exhibition was closed for the advance of COVID 19 virus. In the 'great hall' - as the main space of the ancient Provincial Museum was called - everything remained suspended and perfectly finished: showcases, exhibitors, paintings, statues, clay and stone art objects. However, there was no longer the possibility of letting people, visitors enter. We said that it would have been wonderful to be said that it would have been wonderful to be able to reopen it at least 'virtually'. And so we did, with an immersive and advanced teaching perspective.

Keywords: Italy, museology, exhibition, history of art 


\section{Introduction}

Twenty-five years ago, Catherine Puglisi dedicated the article Guido Reni's Pallione del Voto and the Plague of 1630 on "The Art Bulletin", to the pandemic events of the fourth decade of the seventeenth century and to Guido Reni's painting kept in the church of San Domenico in Bologna. In the essay, the author compared the ferocity of the bubonic plague of 1630 to the equally devastating virulence of the AIDS epidemic in the twentieth century (Puglisi, 1995). The American scholar wrote in 1995, when the sequence of sinister pulmonary syndromes of our days has yet to arrive.

Moving from this reading model, it is not impossible for art historians of 2020 to look at the new great health emergency that has hit the world of the 21st century, with particular regard to the conditioning of the social and cultural life that it has produced. With the same effectiveness as Puglisi's essay, the endless list of coronavirus deaths published on the front page of the New York Times on May 24, 2020, can be compared to that of the dead in Vietnam and for this reason deserving of a second Memorial Wall in black granite. In fact, the capital title reads with excited and understandable emphasis: 'U.S. DEATHS NEAR 100,000, AN INCALCULABLE LOSS'. Consider how the conscripts who died in Vietnam between 1965 and 1972 were 'only' 17,318!

In light of such a communicative choice, it seems necessary to think of the coincidence with the disastrous losses and with the attitudes also held in Italy due to a virus that can be defined as an 'invisible enemy'. One could also think of the initial bold presumption of some of our fellow citizens and rulers in facing the unknown. All this before the army took to the field. All this before the squares, streets and churches of our cities emptied, becoming in spite of themselves witnesses of a 'suspended time' functional for the reports of more or less sensitive photographers. All this before the museums, as well as the countless exhibitions housed in their rooms, were closed, leaving hundreds of thousands of works orphaned to the public (Leonardi, 2020a).

From a certain point on, even the rainbow banners with the words \#andràtuttobene - actually senseless and inadequate from the beginning - began to fade from the website home pages and from the facades of the emptied buildings of public institutions. Among these, the nineteenth century Palazzo degli Studi in Bari already home to a museum destroyed at the beginning of the new millennium by the virus (or plague?) Of the 'renewal' as an end in itself and without the compass of a good project.

Italy, as well as the Bari exhibition here subject of interest (Bari, Palazzo Ateneo, The Museum that does not exist. Art, collecting, antiquarian taste in the Palazzo degli Studi of Bari 1875-1928, from February 28 to April 24, 2020), had to stop before the advance of COVID19, like the rest of the planet and almost reproposing the script for a film that has returned as incredibly topical as Contagion (2011). All this happens exactly as the Italian States had to stop on the occasion of one of the main infectious waves of the Baroque century that inspired formidable artists, such as the Bolognese Reni, author of the aforementioned Pallione del Voto. 
The possible examples relating to the Italian case are naturally very different from each other, especially in relation to what Francis Haskell has called 'ephemeral museums' (Haskell, 2008), that is, the exhibitions. The debate had already started on this issue before the pandemic (Montanari - Trione, 2017). The exhibitions, being temporary events by definition, for this reason have suffered more from the effects of this new 'time of distance' which has interrupted the link between cultural heritage and the public, highlighting the fragility of an entire system which - based on the triad protection-promotion-enjoyment - was born for an objectively 'other' world.

COVID19 has made it necessary to rethink the dialogue with visitors, a dialogue already in crisis and now complicated by the need to do it 'on the run'. It will probably be possible to verify the effects of unprecedented circumstances only in the long term, as well as the scientific stability of the various popular formats linked to the innumerable and sometimes questionable (even only in terms of taste) proposals online.

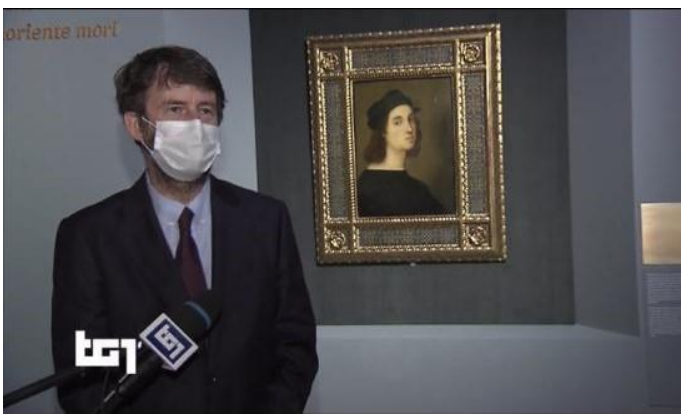

Fig. 1: The Minister of Cultural Heritage at the post-covid reopen of 'Raffaello 1520$1483^{\prime}$

It is possible to list here some of the realities that in recent months have been able to count on a strong media exposure, taking into account the weight and the obvious differences. Among the various initiatives that it will be interesting to continue to monitor over time and for the communication strategies put in place, it therefore seems useful here to recall the webinar sessions dedicated by the curators to the paintings and drawings of Raphael selected for the 500th anniversary of his death (Rome, Scuderie del Quirinale, Raffaello 1520-1483, from 5 March to 2 June 2020, postponed from 2 June to 30 August).

A first initiative is offered by the incursions of an idol of young people such as the youtuber Luis Sal, influencer for the tables of the Griffoni Polyptych, gathered after three hundred years from their dismemberment (Bologna, Palazzo Fava, La riscoperta di un capolavoro. Il Polittico Griffoni, initially scheduled from March 12 to June 28, then postponed from May 18 to January 10, 2021). A second case is represented by the stubborn will to reopen in presence to return to offer the perennial beauty of the eighteenth century with the statues of Canova (Rome, Palazzo Braschi, Canova eterna 
bellezza, from 9 October 2019 to 21 June 2020, reopened to the public on 19 May). To all this must be added, in the writer's opinion, the 'denied' story of Simone Peterzano's paintings, these even blocked in what has become the Italian Wuhan for journalistic reports (Bergamo, Accademia Carrara, Tiziano e Caravaggio in Peterzano, from 6 February to 17 May 2020, with no possibility of extension), a situation perceived as so dramatic as to obtain the extension of an exceptional and solitary loan - almost a gesture of human pietas - such as that of I Musici di Caravaggio from the Metropolitan Museum of Art in New York.

\section{Research lines for a resilient exhibition project}

The exemplary case taken into consideration obviously moves from the same circumstances, i.e. the early closure for COVID19. The exhibition event (Bari, Palazzo Ateneo, the Museum that does not exist. Art, collecting, antiquarian taste in the Palazzo degli Studi of Bari 1875-1928, from February 28 to April 24, 2020) allowed to bring 'home' works such as Antonio Vivarini's Saint Antonio and Lorenzo Lotto's Saint Felice in the chair, both pursued by Bernard Berenson during his Apulian 'pilgrimages'. Without wanting to compare the event to the exhibitions listed above, however, it was in all respects a 'research exhibition'. The result was achieved without clamour, step by step and released from the logic of the 'event' at all costs, within the framework of a consolidated line of work which, since 2016, has been able to express itself through specific programs survey funded by the University of Bari 'Aldo Moro' and of which the writer was scientific coordinator. Among these, it is possible to remember Collezionismo e processi di musealizzazione tra Puglia e Basilicata in Età Moderna e Contemporanea which led to several preparatory publications for the exhibition we are talking about, to conferences, to dedicated teaching programs and seminars, involving colleagues from other universities, students and PhD students of the University of Bari.

Precisely on the thematic line expressed by this project, it is still possible to remember the jokes exchanged with the late Gianni Carlo Sciolla (University of Turin) when, together with Giuseppe De Sandi, among the authors of the essays in the catalogue, he was presented with a contribution for the 'Annali di Critica d'Arte' magazine dedicated to these topics (Leonardi - De Sandi, 2016). Sciolla immediately noticed that the essay could be an effective response to the inexplicable void that occurred on these aspects - straddling art history, collecting and museology- in a sensitive quadrant of southern Italy, where, with all evidence, the historians of the hitherto they had preferred to orient themselves on 'other' lines, obliterating however the extraordinary legacy of scholars such as Adriano Prandi, Michele D'Elia, Pina Belli D'Elia and Maria Stella Calò Mariani.

Precisely on the thematic line expressed by this project, it is still possible to remember the jokes exchanged with the late Gianni Carlo Sciolla (University of Turin) when, together with Giuseppe De Sandi, among the authors of the essays in the catalogue, I proposed him an essay for the 'Annali di Critica d'Arte' magazine dedicated precisely 
to these topics (Leonardi - De Sandi, 2016). Sciolla immediately noticed that the essay could be an effective response to the inexplicable void that occurred on these aspects - straddling art history, collecting and museology - in a sensitive quadrant of southern Italy, where, with all evidence, the art historians had preferred to focus on other lines of research, obliterating the extraordinary legacy of scholars such as Adriano Prandi, Michele D'Elia, Pina Belli D'Elia and Maria Stella Calò Mariani.

Four years after that essay, with a careful campaign of archival reconnaissance carried out first on the Apulian-Lucanian 'territory' and then between Florence, Rome and Naples, it was possible to bring to the attention of a not only specialist public an almost totally unpublished picture that certainly concerns in the first instance the Bari museum, but also what was 'around' and 'outside' it, as demonstrated by the opening to the important story of Jatta collecting.

Of course, the exhibition - curated together with colleague Luisa Derosa - was born first of all from a sharing of intent between the University of Bari 'Aldo Moro' (MUR) and the Polo Museale della Puglia (MiBACT). However, it could not have seen the light without the decisive financial contribution of the Puglia Region, which here takes the opportunity to thank, together with Fabrizio Vona and Mariastella Margozzi (at various times both directors of the Polo Museale della Puglia), in addition to the Magnificent Rector of the University of Bari, at that time Antonio Felice Uricchio, now president of the Executive Board of ANVUR, and to all members of the Scientific Committee such as Maria Giulia Aurigemma (University of Chieti-Pescara), Massimiliano Rossi (University of Salento) and Alessandro Rovetta (Catholic University of the Sacred Heart).

It seems useful to remember how the Provincial Museum, whose space fell precisely in the current Palazzo Ateneo, made the due proportions and almost a century later, replicated the logistical situation created in Naples in the seventies of the eighteenth century, when the Palazzo degli Studi ( initially Cavallerizza and then adapted for the University) it was thought to house not only the sculptures but also the paintings from the Farnese collection of Charles III of Bourbon (Pozzi Paolini, 1977; Leone de Castris, 2000), together with the antiquities found in Herculaneum and to Pompeii. Of course, several factors played a part in the formation of the Provincial Museum of Bari. Among these, the suggestions provided by the Piano per i Musei prepared in 1808 by Michele Arditi, from Salento, since 1807 general director of the Museum of Naples (Milanese, 1996). His Piano for the so-called 'provincial museums' - that is, places outside the Bourbon capital - aimed to create positive repercussions in the areas of the Kingdom "even the most remote and the least cultured", absorbing the debate of the southern reformist illuminists (Antonio Genovesi, Giuseppe Maria Galanti or Gaetano Filangieri) who had taken the field to contain the gap between Naples and the more distant areas.

Preventing the dispersion of archaeological finds and works of art, opening new travel routes for the heirs of the Grand Tour, educating people about taste for art, are some 
of the requests that had already found space in the Arditi Plan and which materialized just after the unification of Italy, specifically with the foundation of cultural infrastructures such as the Provincial Museum which opened its doors in 1890, although it had been talked about since 1875 (Leonardi, 2017). The Bari museum was endowed with a double soul because it was linked both to the antiquarian ambitions and to the artistic ambitions of a rising mercantile traction ruling class. It is no coincidence that these were the years that starred Giovanni Jatta junior, inspector for the 'excavations and monuments' since 1875, who received the assignment from the Ministry of Education at the time to encourage the institution of a museum functional to safeguarding of "precious monuments" and to "increase the centres of scientific activity". A similar choice was the consequence of his commitment on the private side, since his grandfather Giovanni senior had already indicated him in his will as custodian of the famous family 'museum' in his native Ruvo, today the National Jatta Museum, where there was also an important picture gallery.

\section{The architecture of the exhibition}

As for the first 'work' that was brought on display, it is precisely the building in which the ancient Provincial Museum, the Palazzo degli Studi di Bari, has been placed, the result of a project selected by a personality of refined culture such as Emilio De Fabris. Note how De Fabris was the one who in Florence took care - in the second half of the nineteenth century - of important assignments of the newly reunited Italy: from the facade of Santa Maria del Fiore, to the museum display of Michelangelo's David at the Academy. On display, the visitor was able to appreciate the historical plans of the building, illustrating its various functions - including the museum ones - designed by the winner of the competition chaired by De Fabris, the Neapolitan Giovanni Castelli. They were then accompanied by the elegant letters of the one who was called to perform the fresco decorations of the Chapel, the Theatre and the rooms of the Museum, the Bolognese Rinaldo Casanova, an artist very active not only in Southern Italy (in Capodimonte he will deal to set up the Farnesian armory), but also in England, in London, where for example he intervened in the building of the Salviati Manufacture in Regent Street, today the headquarters of the Apple Store (Leonardi, 2020b). 


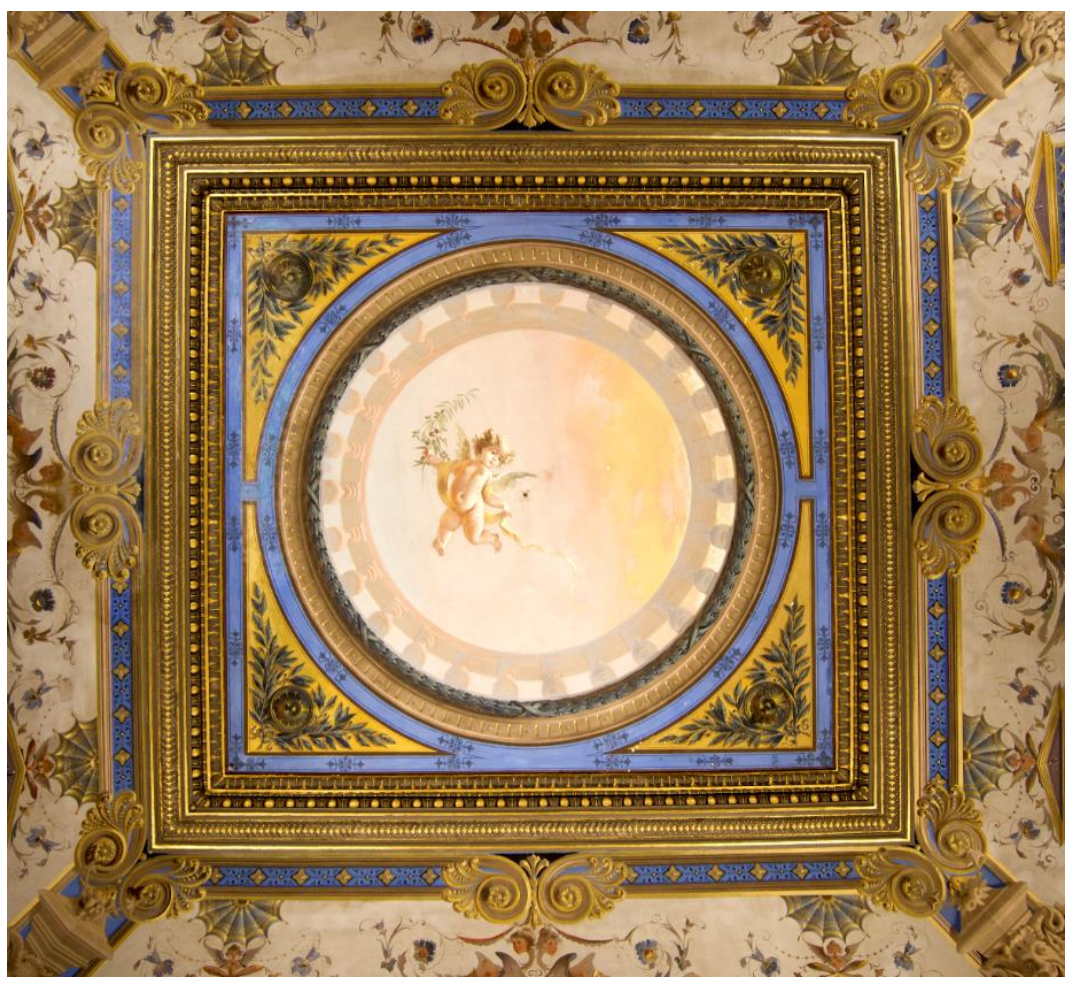

Fig. 2: Frescoed ceiling by Rinaldo Casanova. Palazzo degli Studi, Bari.

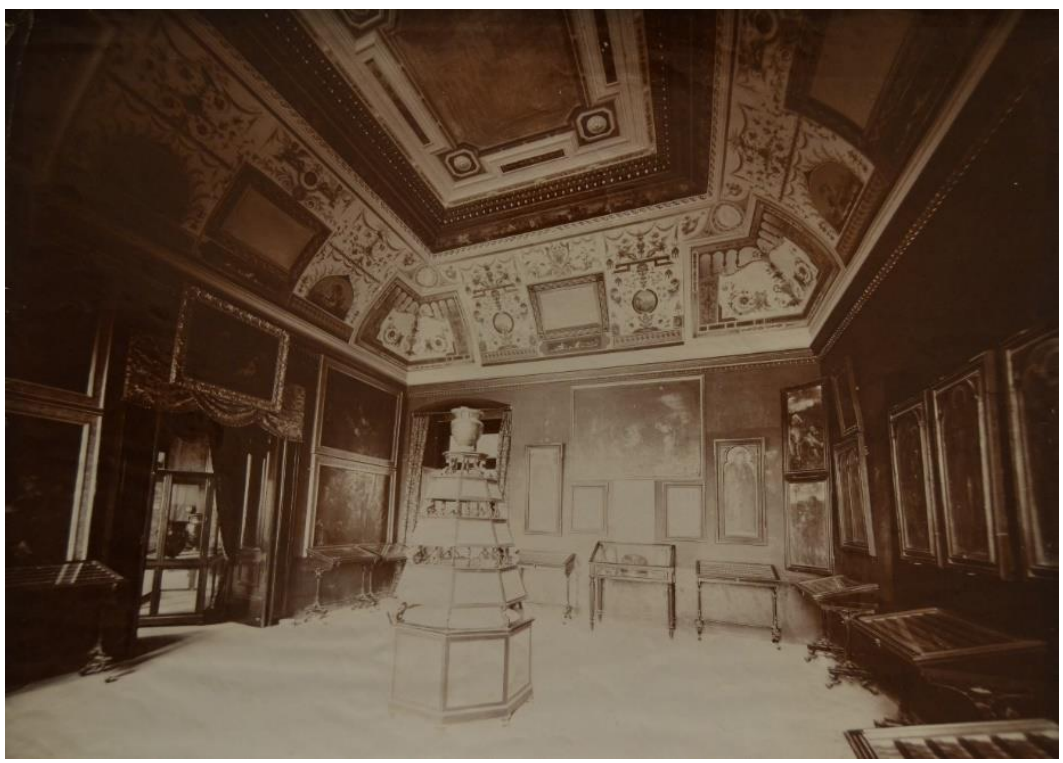

Fig. 3: The ancient Pinacoteca in the Palazzo degli Studi of Bari. 1890-1910. 
The Bari exhibition told about several elements that contributed to the creation of the museum 'container'. Among these, the essential archaeological-antiquarian component, well represented by the 'niche' described by Giuseppe Ungaretti who saw 'the most extraordinary baroque' in some canosine vases of 'twenty-two centuries ago' (1934) (Ungaretti, 1969), as well as the first finding that made its entrance to the Museum, a 'crockery' from the 5th century BC with the 'Stories of Theseus'. There was also attention for the Middle Ages rediscovered with the construction sites of the Apulian religious buildings, beautifully testified by the 'capitello degli schiavi' of the Master of the Chair of Abbot Elia, even 'posed' in a historical photograph by Corrado Ricci reproduced on the didactic panels of the exhibition itinerary. Afterwards, the visitor was able to realize the fortune of figurative culture of Venetian origin in Puglia, with Antonio Vivarini's 'Sant'Antonio da Padova', the strong point of a picture gallery - we will see the future Pinacoteca Provinciale - where the Venetian component was the undisputed protagonist. Finally, the contribution of the art market has proved essential for this newly founded museum: specifically, this chapter was narrated through the 'Sposalizio mistico di Santa Caterina' attributed to Guercino, but considered by Roberto Longhi to be the work of the Genoese Domenico Fiasella, on which, still recently, there has been the possibility to exchange some happy jokes with the art historian Carlo Bertelli.

As mentioned above, the exhibition told not only what happened 'inside' the Provincial Museum, but also what happened 'around' and 'outside'. In the first case, the passage of illustrious visitors such as Bernard Berenson, who arrived in Puglia for the first time in 1897, was evaluated. Berenson visited the Museum in 1907 attracted by its nucleus of Vivarini works, then continuing to have relations with the Puglia until at least 1952, in turn making it known to his friend and patron Edward Perry Warren (De Sandi - Leonardi, 2020). We will limit ourselves here to remember how Warren was so intimate of Berenson that he was the recipient of the dedications of the first two editions of his monograph on Lotto (that of 1895 and that of 1901). He is also the one who purchased a magnificent volute crater and then sold it to the Bari Institute. Precisely because of these connections, it was decided to show the 'San Felice' executed by Lotto for the town Giovinazzo, putting it into the system so much with Berenson's choice to identify an ideal city in the centre of not far Altamura, in the Murgia, where to take refuge (this happened from the pages of the magazine 'The Golden Urn' of 1897), as well as with the diaries and sketches of his wife, Mary Costelloe. The latter generously loaned from Villa I Tatti - The Harvard University Center for Italian Renaissance Studies. In this sense, it was extraordinary to be able to borrow the notebook that contains the design of 'our' San Felice accompanied by the considerations of the famous connoisseur (Leonardi, 2020c).

Finally, the 'out-museum' was well represented by the unprecedented events of a nineteenth century collectionism that gave shape to 'containers' conceived as private but which, since their origin, were also opened to the public with a specific mission:' to educate to taste '. In particular, this is what happened with the 'museum' of the Jatta 
family in its palace in Ruvo, today partly home to the National Museum, from where a very precious sphinx-shaped rhyton arrived for the occasion, which certainly in the residence in the question was accompanied by paintings of absolute value, including a 'Lucrezia' by Artemisia Gentileschi. This painting is recently dispersed on the antiques market, which means a serious cultural impoverishment for not only the regional heritage. Also in this section, there was the possibility of also telling what exceptional happened immediately after 1928, the closing date of the Provincial Museum. This is the commitment of Federico Hermanin, German born in Bari and director of Palazzo Venezia during the twenty years (Nicita, 2000), who will send paintings from the Corsini and Barberini Galleries in Rome to the Apulian capital including Luca Giordano on display - to graft them onto the pictorial nucleus of the ancient Provincial Museum (the Museum That Was There, That Has Been and Has Never Been) thus giving life to a new and independent Pinacoteca (Hermanin, 1930).

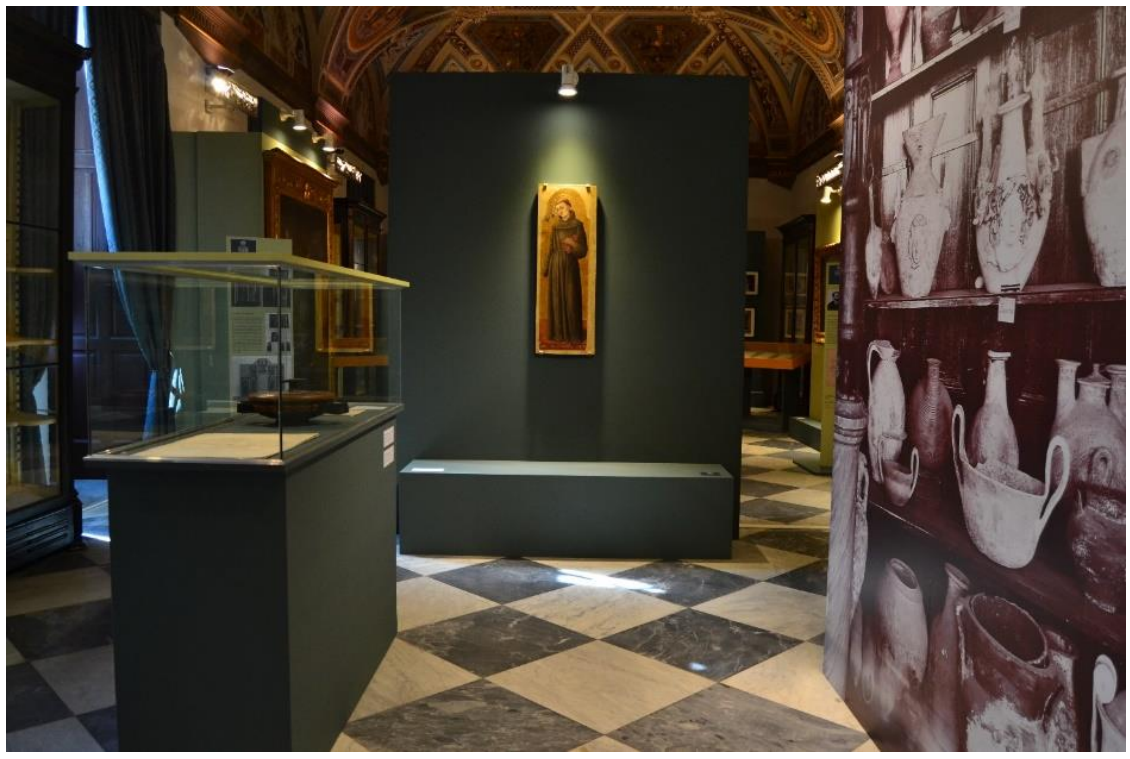

Fig. 4: Saint Antonio by Antonio Vivarini and the riproduction of Ungaretti's niche.

\section{Before Covid-19: the exhibition as an immersive research and teaching means}

The difficulties were not lacking, although support from various institutions did not fail. Firstly by the Puglia Region and the 'Aldo Moro' University. Secondly, by the numerous lenders (Villa I Tatti - The Harvard University Center for Italian Renaissance Studies; Central State Archive; Jatta National Museum; Archaeological Museum of Santa Scolastica; Pinacoteca Corrado Giaquinto) who with their availability have guaranteed the return at home '- in Puglia - of works of fundamental importance. However, an essential factor in the executive phase of the project was to rebuild a 'supply chain' capable of governing all the steps of the realization process of 
an exhibition: scientific, logistical, insurance, set-up, safety, up to the publication of the catalogue in the series 'The Voices of the Museum' (Edifir, Florence), founded and directed by Cristina De Benedictis and Antonio Paolucci.

After this experience, the University of Bari can be considered ready to launch new exhibition projects thanks to the impact that the exhibition has generated in the culture and memory of the city. This should be borne in mind especially in a city like Bari which - despite the commendable efforts - still lacks a real cultural infrastructure, net of the Pinacoteca 'Corrado Giaquinto' now in charge of the Metropolitan City.

Arriving in Bari in 2013 at the 'Aldo Moro' University to teach 'History of Modern Art', I was immediately struck by how this city was in Italy the only regional capital without a National Gallery and without a real and its museum network, despite the repeated unrealistic attempts linked to the contemporary (the ex Teatro Margherita) and the Santa Scolastica construction site, promised, promising and expected Archaeological Museum still far from being considered fully open. In a context so 'hostile' to the idea of museum, it is therefore not surprising that the museum institution housed in the Palazzo degli Studi - that is, the one told by the exhibition The Museum that is not there - has never been perceived by most part of the Bari adults as an 'encyclopedic' reality which in fact it has been since its origins.

Furthermore, the fact that for the younger segment of the population - in particular for the students of the University of Bari - there has simply never been a museum (archaeological or generalist at this point, it doesn't matter), leaves us perplexed. From this aspect derives the absence in recent times of an interest in the dismantling of the museum and for the methods of its formation and for the unity of the artistic and antiques collections, as well as the late nineteenth and early twentieth-century layout went to tell. To want to historicize the story, while remaining a step out of the inevitable and understandable tensions between the institutions culturally responsible for this loss, two factors must also be taken into account. The first, is that there has not been a peaceful debate among the experts (except for the 2007 conference coordinated by Luigi Todisco and for some 'voices' out of the choir journalism). The second is that a more incisive reaction from the so-called 'civil society' was lacking in view of the closure, in 2002, of one of the most characteristic elements of the cultural identity not only of the University, but of the entire Southern community. We will limit ourselves here to note that as such, in fact, the art historian Gustavo Frizzoni, a pupil of Giovanni Morelli, had read the Museum visiting it in 1914 and admiring - like Bernard Berenson in 1907 - its core of works of the Venetian Renaissance.

Precisely with regard to the identity value of the works of the Vivarini who marked Bari, Puglia and the Provincial Museum in question, it is to be considered that still in 2013 one of these, the polyptych by Antonio Vivarini with the Christ in Piety and the Saints Ludovico da Tolosa, Francesco d'Assisi, Giovanni Battista and Antonio da Padova (the last one is the signed and dated compartment received in the exhibition), 
was 'chosen' by the Prada Group to be restored in coincidence with the inauguration of its new boutique overlooking the very central via Sparano in Bari. The showroom was opened in the spaces that had once been the historic publisher of Benedetto Croce, Giuseppe Laterza. Well, this work by Antonio Vivarini - like the Provincial Museum and the other figurative testimonies from the Veneto kept there - was for Frizzoni "worthy of a Capital" and therefore proof of mature cultural "independence" of all that vast area of the "province ex regnicola and then Bourbon which, until the unification of Italy, has always taken for granted the excessive protagonism and weight of the capital Naples (Frizzoni, 1914). Beyond all this, the incontrovertible datum is that a true museum and museum fossil, the Provincial Museum in 1928, then the Archaeological Museum until 2002, has been almost completely lost. How such a situation could occur is not easy to say, but it was not the intent of the entire exhibition operation to make a judgment. Compared to all this, however, the hope is that of having returned a mature opinion, from researchers attentive to the historicalsocial context of art, through a catalogue (pp. 376) designed to remain even after the spectacular moment of the exhibition, as well as through the initiatives set up during the three months of confinement coinciding with the exclusion of the public 'in presence' from the exhibition spaces.

\section{During Covid-19. Operational testimonials / 1 (social networks)}

The inauguration of the exhibition, which took place on February 28, 2020, inadvertently became part of the history of the city of Bari and its university as one of the last events carried out according to pre-COVID19 customs. It was in fact possible to welcome a large number of visitors on the occasion of the vernissage, without masks or social distancing, all spectators unaware of the final act of our lost normalcy. In retrospect it is very significant to have 'said goodbye' by starting an operation to recover the identity culture of the places where students and professors have lived (and hopefully they will be able to return to live). Although for a short time, alongside an unfortunately slower response from the teaching staff, the interest of the students was noted, especially of the so-called freshmen, fascinated, but inevitably affected, by an operation to return the memory of spaces intended for teaching and looking, as were those of the Provincial Museum, which unfortunately the University lost in the early 2000s and which has not yet managed to refunctional according to a coherent design.

On March 6, 2020, after only a week of opening to the public, it was necessary to turn off the lights and close the doors of the Provincial Museum again, without knowing when it would be possible to start again. A few days later each of us, undeniably afraid, found himself in front of the screen of his computer or smartphone. Among the sectors that immediately demonstrated good responsiveness, there was the 'culture' sector which has made a great commitment to the digital offer. 


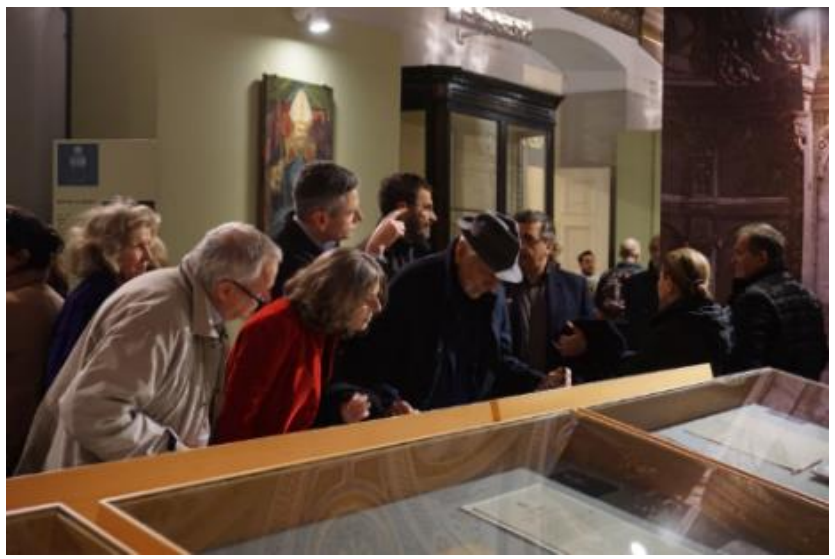

Fig. 5: During the inauguration day of 'Il Museo che non c'è'

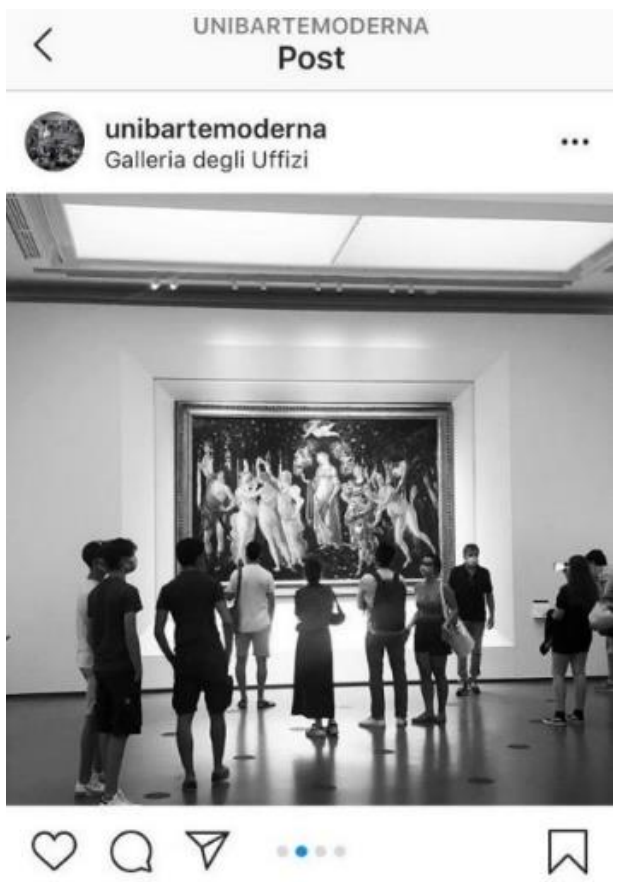

Fig. 6: An Instagram post of @Unibartemoderna.

Without claiming to be complete, it will suffice to mention here how the MiBACT (Ministry of Cultural Heritage and Activities and Tourism) has renewed its YouTube channel, uploading short illustrative videos of those museums, collections and archaeological sites on a daily basis to which the health seals had been placed, finally trying to involve the much-discussed 'non-public' (Solima, 2020). We also tried to intercept the public through a social network with a younger target like Instagram, for which the hashtag \#artyouready was specially designed, which today has more 
than fifty-five thousand posts, slightly less than sixty-three thousand of the hashtag \#mibact. Even individual museum institutions have intensified their attention on these channels. Among the most interesting realities, it is possible to include the Egyptian Museum of Turin which has implemented an already existing section, 'Passeggiate con il Direttore' ('Walks with the director'), transferring it completely to the online platform, and giving life to \#Aportechiuse, dedicated to the protection and enhancement that could, and should, continue to be carried out. A similar initiative was also undertaken by the Uffizi Galleries, which created during the lockdown phase a considerable number of videos, uploaded to their Facebook page, at first only in Italian but then also in English, Spanish and even in Latin. Then coming to explore even more youthful resources like that of Tik-Tok.

In sixteenths, even in Bari the primary objective, which was not obvious could be achieved, was to still be at the service of the project and the public. In this way, the research team operationally engaged on the exhibition 'The Museum that is not there' has decided to develop a narrative appropriate to the new circumstances. Through the Facebook and Instagram accounts of 'Unibartemoderna', webpages already launched with moderate success since 2014 (social networks 1-2) with the aim of offering educational and research support to students of the historical-artistic disciplines of the Bari University, the exhibition story was returned with ten appointments (video 1-10). Each of these dedicated to the issues around which the

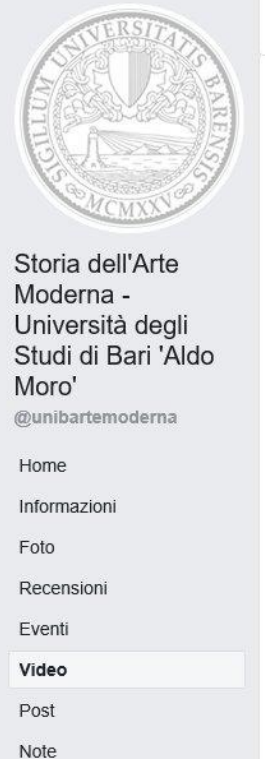

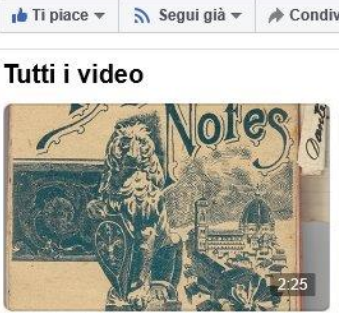

Margherita Nugent 'storica dell'arte' del primo Novecento 10 settimane fa - Visualizzazioni: 303 (1) 10

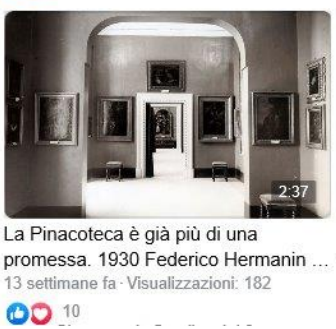

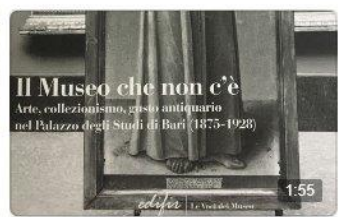

La Mostra che non c'è 11 settimane fa- Visualizzazioni: 380 (1) 1 르 15

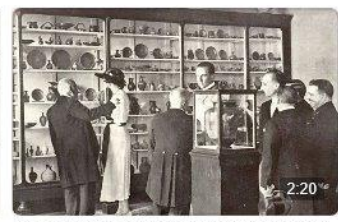

Dall'uno al molteplice. Musei campani dopo l'Unità

ane fa. Visualizzazioni: 464

(1): 24

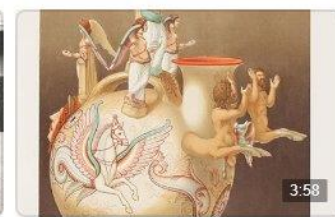

La 'nicchia' di Ungaretti con Raffaella Cassano 12 settimane fa - Visualizzazioni: 403 0021

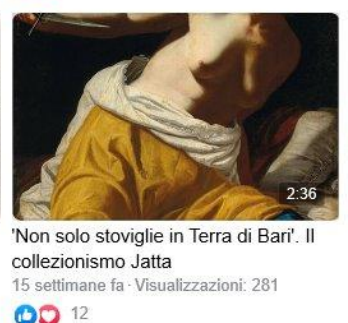

Fig. 7: Facebook's page @Unibartemoderna.

much more 'traditional' organized paper catalogue was built, let us remember again, around what was 'inside', 'around' and 'outside' at the Provincial Museum: 1) 'Il 
Museo che non c'è (più)'; 2) 'The Atheneum' (dedicated to the construction and decoration of the Palazzo degli Studi in Bari); 3) 'Il Medioevo al Museo'; 4) 'Il Rinascimento veneto al Museo Provinciale di Bari’; 5) 'É tempo di agire. Edward Perry Warren e Bernard Berenson'; 6) 'Non solo stoviglie. Il collezionismo Jatta'; 7) 'Dall'uno al molteplice. Musei campani dopo l'Unità'; 8) 'La Pinacoteca è già più di una promessa. 1930 Federico Hermanin'; 9) 'La nicchia di Ungaretti con Raffaella Cassan'; 10) 'Margherita Nugent, storica dell'arte del primo Novecento'. These ten are joined by two others (video 11-12), the "Costruzione del museo effimero' and 'La Mostra che non c'è', respectively concerning the set-up and dismantling of the same. It should be noted that the second occurred, given the impossibility of an extension, in the midst of the transition between the so-called 'Phase 1' and 'Phase 2' of the lockdown imposed by the Italian Government. Faced with this type of communication, the response from the public was more than positive with over four thousand contacts in total, recording an average of 360 views for each of the videos produced, oscillating between the 581 views of the most followed video and the 190 of what has the interest of the public was less aroused.

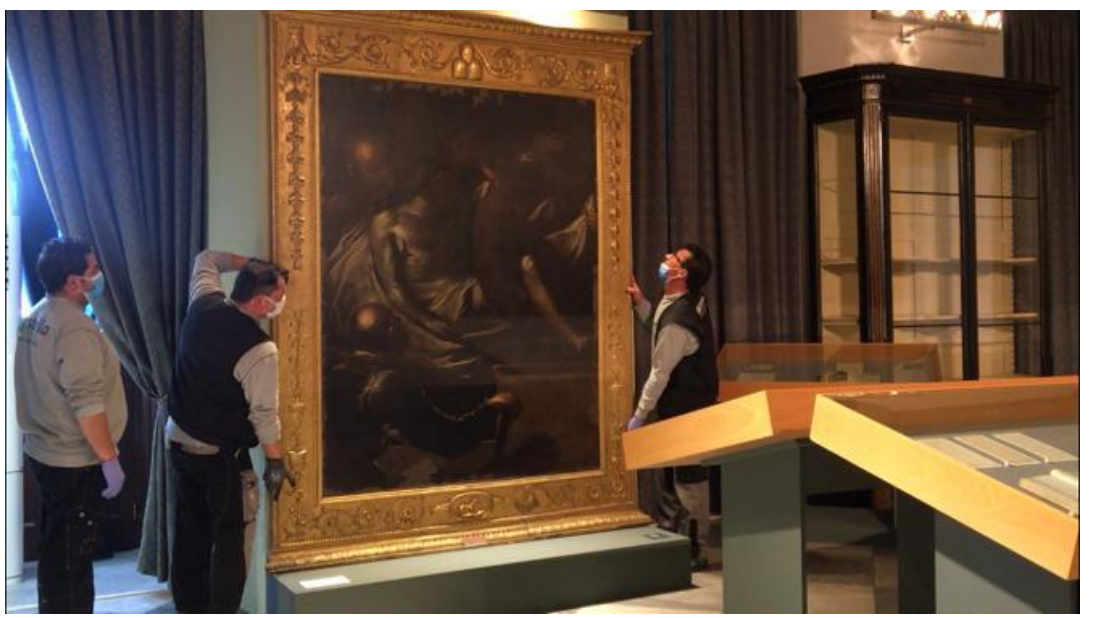

Fig. 8: Dismantling exhibition.

\section{During Covid-19. Operational testimonials / 2 (traditional and new media)}

Perhaps one of the most interesting factors in planning communication was the choice to diversify the offer for the public, not limiting it to the social media channel. The most evident proof of this is the creation of two podcasts for the national radio channel Radio3 Suite, an Italian public radio broadcaster published by Rai (Radiotelevisione Italiana S.p.A). The podcasts, lasting twenty minutes each, aired as part of the 'Impossible Exhibitions' program. Guided visits to Italian museums', a space dedicated to the voices of art historians, critics and archaeologists invited in the circumstance of the health emergency to talk about exhibitions and museums, allowing guided visits to real and imaginary places. The first of the events dedicated 
to the Apulian situation was entitled 'The museum that is not there (anymore)' and gave a detailed account of the exhibition and the related research project at the basis of it (podcast 1). The second, however, is \#weareinpuglia1964. Venetian paintings imported into the exhibition, can be considered as a spin-off of the Bari exhibition, which was blocked by COVID19, having focused attention on a mandatory theme for this southern quadrant: the presence of Venetian artistic production in Puglia between the sixteenth and seventeenth century (podcast 2).The framework of the relationship with the media cannot be defined complete without the analysis of the press review, which started, as usual, with the aim of making the exhibition project known also through the print media, this in order to intercept a certain public perhaps more traditional, but certainly interested by definition in depth. The first article dates back to February 26, a real preview of the exhibition. The interview with one of the curators (Andrea Leonardi) took place during the arrival of the works and appeared on the pages of 'La Gazzetta del Mezzogiorno' with the title 'The Bari Museum that does not exist enchanted Giuseppe Ungaretti in 1934' (Annibaldis, 2020). A second contribution, 'Once upon a time there was the Provincial Museum', of 27 February 2020 , made it possible to reiterate the announcement of the imminent inauguration from the Bari pages of 'La Repubblica' (Totorizzo, 2020a). Arriving below date - the inauguration took place in the afternoon of February 28, 2020 - it was also possible to carry out a professional photographic campaign through the same newspaper ('La Repubblica'), of which a highly articulated gallery was published online - thirty-five images - entitled 'The Museum that does not exist: the treasures of history on display at the University of Bari' (Totorizzo, 2020b). A second article / interview is also dated 29 February, 'When Bari discovered that it also had a Medieval identity. Exhibition on the history of the Provincial Museum' (Di Tursi, 2020a), of the 'Corriere del Mezzogiorno', a magazine which, together with the 'Corriere della Sera', covers the whole of Southern Italy. Note how from the same newspaper, but this time in its online version, a further intervention was also published entitled 'Once upon a time at the University the Provincial Museum' (Di Tursi, 2020b).

Always recalling the idea of a lost heritage, after the so-called 'launch' and the photo gallery dedicated to the exhibition, 'La Repubblica' has returned to giving space to the cultural event with a large article signed by the curator, Andrea Leonardi, Once upon a time (and still is) the Bari Museum (Leonardi, 2020d), released on February 29, 2020. After these days and progressively increasing the restrictions due to the health crisis, the race against time seemed lost. The spaces for any form of communication had in fact been occupied by news relating to the agonizing spread of the virus. After the dismay over the confinement now extended to the whole country (declared by the Presidency of the Council of Ministers on the night of Saturday 7 March), the reorganized response on the subject of institutional communication matured on 24 March thanks to the contribution of 'Canale Arte'.

This media completely dedicated to everything that revolves around the world of ancient and contemporary art, streamed on the website http://www.canalearte.tv/, 
founded in Turin in 2013 and which has become a reference item for the panorama not only Italian, has reserved a large account of the event entitled 'The Museum that is not there (anymore!): an exhibition to remember the Provincial Museum of Bari' (Stroppiana, 2020). Moreover, the attention of the general public towards the contents of the interview given by Andrea Leonardi to Paola Stroppiana is evidenced by the more than nine hundred views that the article can today boast (data updated as of 12.07.2020).

On April 15, when the awareness had already established that it would not be possible to reopen the doors of the exhibition to visitors, the online magazine of S.i.S.C.A. (Italian Society of Art Criticism History) has dedicated a large insert to the exhibition entitled 'The Museum that is not there: the treasures of history on display at the University of Bari' (Petronella, 2020). Finally, the video (Youtube 1) created for the \#PilloleDiCultura section of the Lyceum International Club in Florence (historic women's cultural association) on 22 June, therefore following the dismantling of the exhibition in the second half of May.

Mostre impossibili

Arte, collezionismo, gusto antiquario

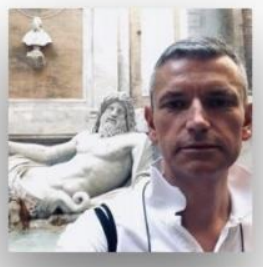

15/04/2020 固 Vai al programma $\equiv_{+}$Aggiungi a Playlist \& Condividi

Coing

Le mostra impossibile di Andrea Leonard

II Museo che non c'è. Arte, collezionismo, gusto antiquario nel Palazzo degli Studi di Bari (1875-1928), allestita nel Salone degli Affreschi dell'attuale Palazzo Ateneo (28 febbraio-24 aprile 2020), in origine sede dell'antico Museo Provinciale. L'stituto si dimostrato un punto di riferimento sia per quanto concerne la 'riscoperta' del Medioevo, sia per quanto attiene le direttrici dell'arte, del collezionismo e della connoisseurship di Età Moderna Sono in particolare le vetrine storiche che ci pariono di presenze 'in assenza': sotto le volte affrescate da Rinaldo Casanova i ripiani sono ancora fl, imbarcati per ricordare ai visitatori il peso dei vasi e delle suppellettili che Cinsieme alla quadreria, incantarono Bernard Berenson,

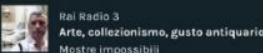

Fig. 9. Podcast in RAI-RADI03-'Mostre Impossibili'.

\section{During Covid-19. Operational testimonials / 3 (Distance learning)}

This type of initiative, placed in a university context - which objectively is not accustomed to 'be a Museum' -, was first of all an opportunity to create a sophisticated research and immersive teaching means. As such it has proved to be decisive to demonstrate - especially to students and $\mathrm{PhD}$ students - that the historical-artistic discipline deals with complexity. Moreover, it also served to disengage from the excess logic of a communication where everything can be called, indiscriminately, 'event' and / or 'exhibition'. It is of no secondary importance to recall what has been 
produced in the context of distance teaching. To satisfy the need to involve the largest possible number of students who have had to follow the teachings of 'History of Collecting' (Second Level Degree in Art History) and of 'Museology and Museography' (Postgraduate Course in Archaeological Heritage) online, it was decided to propose a series of seminars, called 'pandemic seminars', administered on the Microsoft Teams platform. While the first, held by Giuseppe De Sandi, PhD student in Art History at the same University of Bari, was entitled 'Going for exhibitions: the idea of Baroque in ephemeral museums of the early twentieth century'; the second, proposed by Andrea Leonardi, was dedicated to the theme of post-unification museums, 'Italy 1870. Around galleries, art galleries and museums of the new nation'. Among the most innovative teaching experiences, there was finally the appointment proposed to the students of the 'Museology and Museography' course of the aforementioned School of Specialization in Archaeological Heritage. By exploiting the potential offered by distance learning, but without neglecting the direct approach with artistic artefacts and antiques, it was possible to transmit live the dismantling of the exhibition operations, illustrating the different and delicate work phases to the trainees: the packing of canvases, tables, archaeological finds and documents returned to their home; the drafting of condition reports; the focus on restorations made specifically for the exhibition event; the analysis of the specific materials used to ensure optimal and safe transport; the handling techniques adopted. All in keeping with that process of 'immersive teaching' which, although conducted remotely for necessity, has made clear the potential of an effective collaboration between students and teachers who have not missed the opportunity to say that the museum has been there.

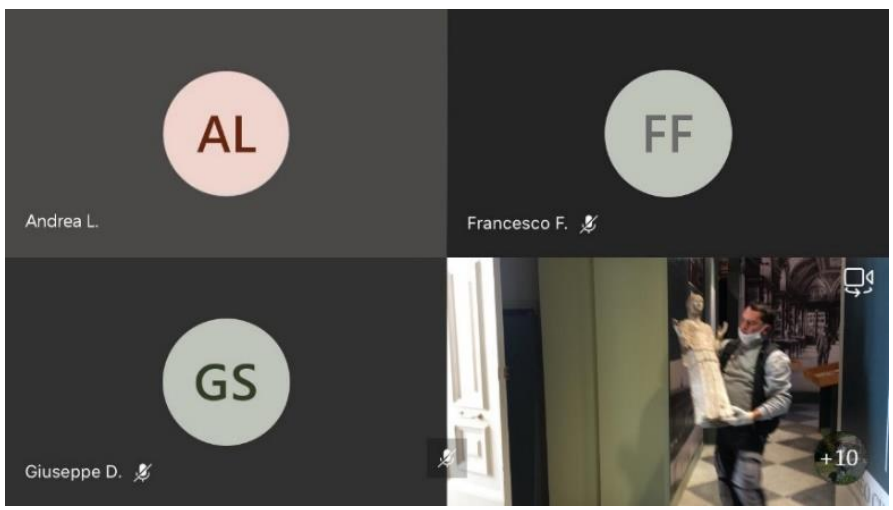

Fig. 10: A moment during the last online-lession.

\section{Conclusion}

Among the most fascinating working hypotheses and on which it was immediately reported to reflect there was the desire to return the idea of a space that - this time permanently - recalls the Museum. From the point of view of scholars who think primarily of art history, but also of museology and museography, it is not possible to 
be opposed to the operation that led in the early 2000s to the transfer of the surviving archaeological collections from the Palazzo degli Studi to the beautiful complex of Santa Scolastica. If, however, we could go back in time, it would be appropriate to invite those who did so to rethink about the possibility of conserving the ancient spaces of the Provincial Museum. Indeed, it would be extraordinary to be able to continue looking at some of the paintings seen by Gustavo Frizzoni, Corrado Ricci and Bernard Berenson, together with a restricted selection of the archaeological finds that 'lived' in the still preserved ancient showcases - and fortunately protected by a pertinent bond - below the vaults frescoed by Rinaldo Casanova. It is precisely those showcases that speak to us of presences "in absence". The shelves are there, still embarked to remember the weight of the vases and furnishings that enchanted Ungaretti and that aren't there anymore. The period of the so-called lockdown is a useful state for reflecting and working on how to return to living this lost identity of formidable value and these lines want to be precisely the engine of such an intention.

* Andrea Leonardi: paragraphs I, II, IV; Giuseppe De Sandi: III, V; Claudia Colella: VI, VII. Conclusions, paragraph VIII, are the result of a common further reflection.

\section{References}

[1] Annibaldis, G. (2020), Il Museo di Bari che non c'è incantò Giuseppe Ungaretti nel 1934. La Gazzetta del Mezzogiorno, 26 febbraio

[2] Berenson, B. (1901), Lorenzo Lotto. An Essay in Constructive Art Criticism, London: Bell

[3] Di Tursi, P. (2020b), Quando Bari scoprì di avere anche l'identità Medioevale. Mostra sulla storia del Museo Provinciale. Corriere della Sera, Corriere del Mezzogiorno, 29 febbraio

[4] Frizzoni, G. (1914), Opere di pittura veneta lungo la costa meridionale dell'Adriatico, Bollettino d'Arte, VIII, 23-40

[5] Haskell, F (2008), La nascita delle mostre. I dipinti degli antichi maestri e le origini delle esposizioni d'arte, Milano: Skira

[6] Hermanin, F. (1930), La Pinacoteca Provinciale di Bari. Japigia. Rivista pugliese di Archeologia, Storia e Arte, I, 74-87

[7] Leonardi, A. (2017), Il sistema del collezionismo nella Puglia storica dell'Ottocento. Gusto antiquario e modelli figurativi per un 'nuovo' museo in Palazzo Ateneo a Bari. In Acanfora, E.-Fontana, M.V. (a cura di) (2017), Cammillo D'Errico (1821-1897) e le rotte mediterranee del collezionismo ottocentesco, 92-105

[8] Leonardi, A. (2020a), «Quell'incrociarsi fatale ed aguzzo di membra» (R. Longhi, 1913). L'immaginario della peste nella cultura artistica di età barocca. In Amendola, G. (a cura di) (2020), L'immaginario e le epidemie, 7196, Bari: Adda Editore

[9] Leonardi, A. (2020b), «The Atheneum». Tempi forme e funzioni per il Palazzo degli Studi e il Museo Provinciale di Bari. In Derosa, L.- Leonardi, A. 
(a cura di) (2020), Il Museo che non c'è. Arte, collezionismo e gusto antiquario nel Palazzo degli Studi di Bari (1875-1928), 50-73

[10] Leonardi, A. (2020c), \#weareinpuglia. Lorenzo Lotto e i pittori veneti in mostra. In Coltrinari, F.- Dal Pozzolo, E. (a cura di) (2020), Lorenzo Lotto: contesti, significati, ricezioni, 433-454

[11] Leonardi, A. (2020d), C'era una volta (e c'è ancora) il Museo di Bari. La Repubblica di Bari, 29 febbraio

[12] Leonardi, A.- De Sandi, G. (2016), Collezionisti, collezionismo e processi di musealizzazione in Puglia tra XVIII e XIX secolo. Annali di Critica d'Arte, XII, 345-374

[13] Leonardi, A.- De Sandi, G. (2020), “E” tempo di agire”. Edward Perry Warren, Antonio Jatta, Bernard Berenson e il mercato artistico-antiquario nella Puglia storica tra musei pubblici e privati (XIX-XX secolo). In Derosa, L.Leonardi, A. (a cura di) (2020), Il Museo che non c'è. Arte, collezionismo e gusto antiquario nel Palazzo degli Studi di Bari (1875-1928), 176-199

[14] Leone de Castris, P. (2000), Nazionale e/o universale? Il Real Museo e la nascita del museo modern. In Ascione, I. (2000), Beni Culturali a Napoli nell'Ottocento, 161-176

[15] Milanese, A. (1996), Il piano arditi del 1808 sui musei provinciali. In I Greci in Occidente, $275-280$

[16] Montanari, T.- Trione, V. (2017), Contro le mostre, Torino: Einaudi

[17] Nicita, P. (2000), Il Museo Negato. Palazzo Venezia 1916-1930. Bollettino D'Arte, LXXXV, 29-72

[18] Pozzi Paolini, E. (1977), Il Museo Archeologico di Napoli in due secoli di vita. In Da Palazzo degli Studi a Museo Archeologico, 1-27

[19] Puglisi, C. (1995), Guido Reni's Pallione del Voto and the Plague of 1630. The Art Bulletin, CXXVII, 3, 402-412

[20] Solima, L. (2020), Management per l'impresa culturale, Roma: Carocci

[21] Todisco, L., (a cura di) (2007), Il museo archeologico della Provincia di Bari tra conservazione e innovazione, Bari: Edipuglia

[22] Totorizzo, G. (2020a), C'era una volta il Museo Provinciale. La Repubblica, 27 febbraio

[23] Ungaretti, G. (1969), Vita d'un uomo. Il deserto e dopo, Milano: Mondadori

\section{Digital references}

\section{Social Networks}

[1] Instagram: https://www.instagram.com/unibartemoderna/

[2] Facebook: https://www.facebook.com/unibartemoderna/

[3] Exhibition videos:

https://www.facebook.com/pg/unibartemoderna/videos/ 


\section{Podcasts:}

[1] Il Museo che non c'è (più!):

https://www.raiplayradio.it/audio/2020/04/Mostre-impossibili-128265fde72a-4bdd-9757-84f20e5fb8df.html

[2] '\#weareinpuglia1964: https://www.raiplayradio.it/audio/2020/06/Mostreimpossibili-Dipinti-veneti-importati-9bff1ddb-84dd-4749-b37f8097248dbaa4.html

\section{Sitography:}

[1] Totorizzo, G. (28 febbraio 2020), 'La Repubblica' https://bari.repubblica.it/cronaca/2020/02/28/foto/bari_museo_che_non_ c_era-249812768/1/\#1

[2] Di Tursi, M. (29 febbraio 2020a), 'Corriere del Mezzogiorno' https://www.pressreader.com/italy/corriere-del-mezzogiornopuglia/20200229/281479278455315

[3] Stroppiana, P. (24 marzo 2020), 'Canale Arte'

[4] https://www.canalearte.tv/video/reportage/mostre/li-museo-che-non-cepiu-una-mostra-per-ricordare-il-museo-provinciale-di-bari/

[5] Petronella, L. (15 aprile 2020), 'SiSCA online' http://www.siscaonline.it/joomla/2019/il-museo-che-non-ce-i-tesori-dellastoria-in-mostra-allateneo-di-bari/ 